УДК 61:378.018.43-047.37-057.87

DOI 10.11603/me.2414-5998.2021.1.11973

\author{
А. В. Вихрущ ${ }^{1}$ \\ ORCID https://orcid.org/0000-0002-1982-0768 \\ ResearcherID I-9562-2017 \\ Н. Б. Вихрущ ${ }^{2}$ \\ ORCID https://orcid.org/0000-0002-8489-7964 \\ I. Д. Драч ${ }^{1}$ \\ ORCID https://orcid.org/0000-0001-7198-5546 \\ О. М. Христенко \\ ORCID https://orcid.org/0000-0001-6036-2829
}

${ }^{1}$ Тернопільський національний медичний університет імені І. Я. Горбачевського МОЗ Украӥни

${ }^{2}$ Львівський національний університет імені Івана Франка

\title{
ПІДГОТОВКА СТУДЕНТІВ МЕДИЧНИХ УНІВЕРСИТЕТІВ ДО СПІЛКУВАННЯ 3 ДІТЬМИ $З$ ОСОБЛИВИМИ ПОТРЕБАМИ
}

\author{
A. V. Vykhrushch ${ }^{1}$, N. B. Vykhrushch ${ }^{2}$, I. D. Drach ${ }^{1}$, O. M. Khrystenko ${ }^{1}$ \\ ${ }^{1}$ I. Horbachevsky Ternopil National Medical University \\ ${ }^{2}$ Ivan Franko Lviv National University \\ PREPARATION OF MEDICAL UNIVERSITY STUDENTS FOR \\ COMMUNICATION WITH CHILDREN WITH SPECIAL NEEDS
}

\begin{abstract}
Анотація. У статті розглядаються актуальні питання комунікаційної культури майбутніх лікарів. Автори аналізують різні підходи до визначення категорії дітей з особливими потребами, які потребують уніфікації. Виокремлено коло завдань, пов'язаних із педагогічною підготовкою майбутніх лікарів до надання медичних послуг дітям з особливими потребами: удосконалення методики викладання навчальних дисциплін етичного спрямування, доповнення змісту навчально-виховної роботи в закладах вищої медичної освіти інформаційними матеріалами про специфіку комунікації фахівців сфери охорони здоров’я з дітьми 3 особливими потребами, формування професійної готовності майбутніх лікарів до просвітницької роботи з батьками «особливих дітей». Визначено базові цінності в контексті культури спілкування майбутніх лікарів з дітьми з особливими потребами, такі, як: пацієнтоцентричність, особистісний підхід, повага людської гідності осіб з особливими потребами, реалізація їх прав та інтересів, створення усіх відповідних умов для ефективної діагностики, лікування й консультації дітей з особливими потребами, співпраця з фахівцями інших сфер та громадськістю щодо всебічної підтримки дітей даної категорії і їх родин. Виокремлено психологічні, педагогічні та філологічні аспекти об’єктивної самооцінки майбутніх лікарів як необхідної умови формування їх комунікаційної культури. Підкреслено важливість емпатії, врахування специфіки майбутньої професійної діяльності, особливості спілкування з дітьми-сиротами, дітьми з інвалідністю. Доведено ефективність нових методів організації навчального процесу, таких, як: взаємне рецензування, самооцінка, експертна оцінка, підготовка опорних схем (mind map). Визначено перспективні напрями дослідження, що пов'язані з упровадженням інклюзивних цінностей у навчально-виховний процес вищої медичної школи.
\end{abstract}

Ключові слова: спілкування; виховання; діти з особливими потребами.

Abstract. The article concerns topical issues of communication culture of future doctors. Authors analyze different approaches to determining the category of children with special needs which need to be unified. Range of tasks related to the pedagogical training of future doctors to provide medical services to children with special needs have been defined: improving the methods of teaching of the ethical disciplines, supplementing the content of educational work in institutions of higher medical education with information materials on the specifics of communication of health professionals with children with special needs, forming of professional readiness of future doctors for educational work with parents of "special children". Basic values in the context of communication culture of future doctors with children with special needs are defined: patient-centeredness, personal approach, respect for human dignity of people with special needs, realization of their rights and interests, creation of all appropriate conditions for effective diagnosis, treatment and consultation of children with special needs, cooperation with specialists in other fields and the public on comprehensive support of children in this category and their families. Psychological, pedagogical and philological aspects of objective self-assessment of future doctors as a necessary condition for the formiтn of their communication culture are highlighted. The importance of empathy, taking into account the specifics of future professional activity, the peculiarities of communication with orphans, children with disabilities have been emphasized.

( А. В. Вихрущ, Н. Б. Вихрущ, І. Д. Драч, О. М. Христенко 
The effectiveness of new methods of organizing the educational process is proved i.e. mutual review, self-assessment, expert assessment, preparation of mind maps. Promising areas of research related to the introduction of inclusive values in the educational process of higher medical school are identified.

Key words: communication; upbringing; children with special needs.

Вступ. Аналіз нормативних документів дозволяє зробити висновок, що підготовка майбутніх лікарів в Україні наближається до міжнародних стандартів, згідно з якими високий рівень професійних якостей поєднується з соціально-гуманістичними характеристиками, зокрема вмінням працювати не лише з пацієнтами, але й членами родини, враховувати специфічні особливості представників різних вікових груп, ефективно спілкуватися, уникати професійного вигорання. Зауважимо важливість декількох проблем. Нам вже доводилося обгрунтовувати необхідність уточнення змісту міжнародних нормативних документів, автори яких називають серед дітей з особливими освітніми потребами осіб віком до 18-ти років, які потребують підтримки в освітньому процесі (діти з інвалідністю; діти з порушеннями психофізичного розвитку; діти-мігранти; діти, які працюють; діти-біженці; представники релігійних та національних меншин; діти із сімей з низьким прожитковим мінімумом; діти-сироти; діти із захворюванням на СНІД/ВІЛ та інші) [8]. На нашу думку, хаотичне поєднання різних категорій дітей потребує критичної оцінки. Такий підхід має як позитивні, так і негативні аспекти. Позитивним $\epsilon$ те, що виокремлено специфіку дітей з певними потребами. Водночас, на нашу думку, порушення прав дитини проявляється в поєднанні різнопланових проблем, зокрема дітей-сиріт, хворих дітей $i$ дітей з вразливих соціальних груп. Зауважимо, що вітчизняні автори здебільшого прагнуть уникати таких недоліків. У «Путівнику для батьків дітей 3 особливими освітніми потребами», виданому Інститутом спеціальної педагогіки НАПН України, виокремлено такі групи дітей з особливими потребами: діти із затримкою психічного розвитку, діти із порушенням слуху, діти із порушенням зору, діти з порушенням розумового розвитку, діти 3 церебральним паралічем, діти з порушенням мовленнєвого розвитку, діти з аутизмом, гіперактивні діти [7]. Щоправда, інколи цей перелік розуміють ширше, доповнюючи групами дітей, потреби яких у цілому виходять за межі «загальноприйнятої норми», це: діти із соціально вразливих груп (наприклад, вихованці дитбудинків), обдаровані діти, які теж можуть потребувати особливого ставлення з боку медичних працівників [9, с. 116].
Упродовж останніх років увага до професійного спілкування лікарів і студентів медичних університетів стрімко зростає. Проблема спілкування в контексті професійної підготовки майбутніх лікарів та професійної діяльності лікарів-практиків достатньо повно репрезентована в сучасній науці. Так, О. Гомотюк вивчає основи педагогічного спілкування, що виступає методологічною базою формування комунікативної культури студентів закладів вищої медичної освіти. В. Дроненко, Т. Грузєва, Л. Федонюк аналізують технології розвитку комунікативної компетентності майбутніх лікарів у процесі професійної підготовки. Л. Фоміна досліджує проблему формування культури спілкування в студентському середовищі закладів вищої медичної освіти. О. Шаніна вивчає комунікативно-прагматичний аспект медичного дискурсу, що становить науковий інтерес для розуміння теоретичних засад розвитку культури спілкування майбутніх фахівців сфери охорони здоров'я.

Специфіку комунікації у професійній діяльності лікарів-практиків досліджують І. Рогач, Л. Качала, Р. Погоріляк (спілкування в процесі ефективної лікарської діяльності), Н. Біденко (питання комунікативних навичок лікаря-стоматолога), А. Мединська, С. Коноваленко (особливості вербального спілкування медичних працівників), В. Зливков, С. Лукомська (основи психології спілкування медичних працівників).

Мета статті - розглянути актуальні питання підвищення рівня комунікативної культури майбутніх лікарів, обгрунтувати ефективність сучасних методів організації навчального процесу.

Теоретична частина. Вивчення особливостей роботи з дітьми, які мають певні порушення психофізичного розвитку, - одна з актуальних проблем сьогодення. Україна приєдналася до Конвенції про права осіб з інвалідністю (далі - Конвенція) 6 березня 2010 р. 3 цього часу держава взяла на себе зобов'язання захищати права та гідність людей 3 обмеженими можливостями. Відповідно, було створено посади Уповноваженого Президента України 3 прав людей з інвалідністю, Урядового уповноваженого $з$ прав осіб з інвалідністю, діє Рада у справах осіб з інвалідністю при Кабінеті Міністрів України, які здійснюють експертизу законів, а також подають 
на розгляд власні пропозиції, реалізують проекти щодо створення відповідних умов для таких категорій населення. Зокрема, досі чинною є Постанова Верховної Ради України «Про Рекомендації парламентських слухань на тему: «Освіта, охорона здоров’я та соціальне забезпечення дітей з порушеннями психофізичного розвитку: проблеми та шляхи їх вирішення» від 13 січня 2015 р.

Толерантне співжиття з особливими людьми в суспільстві залежить від сімейного та шкільного виховання, а забезпечення прав дітей і дорослих 3 вадами розпочинається з підготовки майбутніх спеціалістів різних галузей народного господарства в університетах та коледжах. Питання спеціальної освіти та спеціальної педагогіки є одним із пріоритетних напрямів державної політики і наукового інтересу вчених [5, с. 21], водночас розробки у сфері забезпечення прав дітей на охорону здоров'я досі не стали комплексними та системними [2]. Надання медичної допомоги дітям з інвалідністю є об’ єктом постійного інтересу лікарів та вчених-медиків, проте педагогічний аспект підготовки майбутніх медичних працівників до роботи з неповнолітніми 3 особливими потребами випадає з уваги, хоча право на здоров’я, абілітацію та реабілітацію є окремими статтями згаданої Конвенції [6]. Відсутність знань, навичок, необ’ єктивне ставлення до пацієнтів-дітей з обмеженими можливостями можуть негативно вплинути на результати лікування, що особливо недопустимо під час роботи з молодими особами. Окремої уваги заслуговує почуття самотності таких дітей [13, с. 74]. У єдиній на сьогодні Всесвітній доповіді з проблем інвалідності ВООЗ (2011) на основі аналізу ситуації в 51 країні зазначається, що люди з особливими потребами у два рази частіше стикаються з невідповідністю знань і навичок постачальників медичних послуг потребам хворого; ймовірність неуважного ставлення до хворого - в чотири рази вища; а ймовірність відмови від надання медико-санітарної допомоги - приблизно в три рази вища, ніж для інших пацієнтів [4, с. 10].

Відповідні знання студенти отримують у процесі підготовки в інтернатурі: отоларингології, офтальмології, психіатрії, травматології, магістерських програм з фізтерапії, ерготерапії тощо, тож нагальним є і перегляд програм з дисциплін на кшталт «Лікарська етика» та «Медична деонтологія» як наскрізних у процесі навчання майбутніх працівників лікувальної/фармацевтичної сфери; інших навчальних дисциплін, принаймні тих, які найчастіше можуть бути пов'язані із психофізіо- логічними відхиленнями. Вже на етапі першого звернення до лікаря, стоматолога чи аптекаря пацієнт повинен бути захищений від негативних наслідків упередженого ставлення. Ці компетентності формуються як спеціальними дисциплінами, так і інтегральними результатами навчання, що можуть бути передбачені під час вивчення різних предметів у процесі здобуття вищої медичної освіти.

Задля покращення професійної діяльності, підвищення рівня знань та навичок представників служб охорони здоров’я, «навчання медичних спеціалістів повинне включати в себе необхідну інформацію, що стосується інвалідності» [4, с. 14]. У тому числі запропоновано залучати людей з особливими потребами як надавачів такої інформації, а також - забезпечити розширення їхніх прав та можливостей, зокрема в самодопомозі, що в результаті дозволить їм краще контролювати стан свого здоров'я [4, с. 13].

Все вищесказане обумовлює необхідність удосконалення форм і методів навчання майбутніх лікарів. Розглянемо окремі аспекти підвищення комунікаційної культури студентів.

Автори академічного словника української мови розглядали спілкування як «взаємні стосунки, діловий, дружній зв'язок». Це не зовсім вдале визначення, оскільки спілкування є лише елементом взаємних стосунків, ділових і дружніх зв’язків.

У контексті нашої праці важливим є висновок психологів про завдання медичної психології, серед яких виокремлено анамнез - вивчення «минулих переживань пацієнта від раннього дитинства до моменту настання хвороби», а також ятрогенії.

Серед батьків і дослідників особливу зацікавленість викличе характеристика вигорання батьків дітей з особливими потребами [3]. Вивчення думки батьків дітей з аутизмом і синдромом Дауна дозволило польським дослідникам виокремити такі аспекти, як: втома, викликана неперервною опікою, почуття самотності і потреби допомоги, відчуття неможливості суттєвих змін у житті, безнадійність, відсутність умінь і знань на тему виховання хворої дитини, відповідальність за долю дитини, нерозуміння з боку відповідних інституцій, неясність щодо можливостей дитини, негативна атмосфера в домі, небажання віддати дитину у відповідні заклади і докори сумління за такі думки, фізична втома, фрустрація. Підкреслимо одну важливу особливість. Кількість проблем значно перевищує кількість порад щодо полегшення (навіть не вирішення) проблеми. Серед них групи самодопомоги, 
індивідуальна терапія, інформування батьків [12].

Способи опанування зазначених аспектів медичної освіти в процесі навчання не усталені ні у вітчизняній, ні у світовій методиці викладання, проте більш продуктивною видається практика наскрізного компонента, який дозволяє, по-перше, не переобтяжувати навчальний план студентів медичних спеціальностей окремими дисциплінами, по-друге, передбачає засвоєння необхідних знань та навичок студентами усіх спеціалізацій, а не лише тих, які потенційно найчастіше працюють 3 дітьми з особливими потребами. В курикулумі «Навчання студентів медичних спеціальностей піклуванню про людей з особливими потребами: розвиток та початок реалізації» дослідники підкреслюють негативний вплив стереотипів та браку знань медичного персоналу про людей з обмеженими можливостями на процес та результати лікування і пропонують власний вихід із ситуації. Як результат - підготовка «універсального» медика, підвищення якості надання медичних, стоматологічних, фармацевтичних послуг для всіх категорій населення незалежно від віку, стану здоров’я, соціального статусу. Автори окреслюють специфічні цілі та прогнозовані результати навчання, які дозволять уникнути цього браку знань: 1. Набуття знань про вади, розвіяння стереотипів; 2. Прищеплення альтруїстичного ставлення і відданості у процесі допомоги людям з особливими потребами; 3. Сприяння розвитку навичок, необхідних для догляду та лікування таких пацієнтів [10]. Реалізація цих цілей передбачає засвоєння інформації та набуття вмінь, які, зокрема, перегукуються з висновками ВООЗ. Дослідники передбачають оволодіння знаннями про типи, характер, причини вад та їх поширення, поведінкові проблеми, зокрема в сім’ї, про принципи та клінічні підходи до задоволення специфічних потреб. Окремий пункт - інформація про доступні ресурси, послуги, урядові та неофіційні спільноти. Основні навички, які необхідно здобути: пацієнтоцентричність, вміння бачити людину «крізь інваліда», в тому числі дотримання прав та виконання побажань, ефективна діагностика, відповідне роз'яснення та отримання згоди таких пацієнтів як на подальші процедури, так і на подальші направлення до «вузьких» фахівців, у громадські організації [10].

У матриці до курикулуму передбачено лекційні та семінарські заняття, роботу зі стандартизованим пацієнтом, зустрічі з реальними пацієнтами та їхніми сім’ями, правозахисниками, можливість відві- дання громадських організацій, клінічну практику та можливість досліджень. Така підготовка студентів медичних спеціальностей до роботи з дітьми 3 особливими потребами дозволить, на нашу думку, вирішити сучасні проблеми з такими категоріями пацієнтів і в майбутньому доповнить знання та методи роботи педагогів із цією групою населення.

У процесі навчання студентів ТНМУ викладачі використовують різноманітні форми і методи [11]. Особливу зацікавленість серед студентів викликає обговорення дискусійних, оригінальних матеріалів. Наприклад, до Дня людей з інвалідністю проведена дискусія щодо змісту публікації Мар’яни Бобрівець, яка у своєму блозі написала: «День людей з інвалідністю. У стрічці чимало постів від осіб, дотичних до теми. Довго думала, чи писати щось і собі. Бо в мене оточення нібито адекватне - його не треба ні напучувати, ні вчити, ні інструктувати. А тим, кого треба, зазвичай писанина не допоможе. Та ось що скажу. Пандуси, комфортний громадський транспорт, спеціальні гойдалки на дитячих майданчиках - це необхідно, важливо, круто. Але, знаєте, звідки все починається? Де насправді народжується інклюзія? Інклюзія починається з наших голів. Мислення і думок.

Люди з інвалідністю - насамперед люди. Звичайні люди, які люблять музику, спілкування, милуватися заходом сонця. Ненавидять корки на дорогах, бояться болю і тішаться першим снігом. Так само, як і ви.

Насправді люди з інвалідністю - не особливі. Особливе лише здоров’я. У них така ж усмішка і такі ж сльози, як у всіх. I їм не потрібний жаль. Драма. Потоки чужого співчуття. Вони не об’єкти для піару. I не тренажери для виховання милосердя в підростаючому поколінні.

Так, їхнє здоров’я потребує пильнішої уваги. Але більшість уміє з цим жити. I не повірите, але добра частина не згадує про свою інвалідність, поки їм про це не нагадають. Не адаптоване середовище в місті. Необлаштовані школи. А може, «тактовний» роботодавець під час співбесіди?

Єдине, що їм необхідне - доступність. Доступність міських вулиць, навчальних закладів, автобусів. Доступ до лікування і медикаментів. До повноцінного навчання, можливості працювати.

Я знаю, що більшість з вас не в силі змінити ці обставини. Вплинути на владу, «розвернути» потрібні реформи, обладнати пандусами всі магазини, встановити звукові світлофори тощо. Але від нас цього ніхто й не вимагає. Хіба, якщо маєте змогу, 
більше говоріть із дітьми про те, що люди приходять у цей світ дуже різними і це нормально. Зробите потужні інвестиції у майбутнє.

Найбільше, що ви можете зробити для людини з інвалідністю, перебуваючи поруч із нею, - бути собою. Поводьтеся природно. Зрештою, не бійтеся спілкуватися з нею. Дивитися кіно. Їсти морозиво. Грати у сніжки. Співпрацювати. Обговорювати модні луки. Сміятися з анекдотів. Побачити в ній особистість.

Тільки будьте готовими: тоді ви, скоріше за все, забудете про її інвалідність. Бо люди з інвалідністю - насамперед, люди» [1].

Особлива увага звертається на об'єктивну самооцінку майбутніх лікарів. Цей аспект дозволяє виокремити психологічні, педагогічні, філологічні проблеми. Не змінюючи авторського тексту, розглянемо декілька прикладів самооцінки при виконанні завдань у процесі вивчення української мови за професійним спрямуванням. Студенти оцінювали свої виступи перед групою.

1. «Зараз головне моє завдання полягає в тому, щоб чесно оцінити себе. Для мене це не легко, адже я себе не чула, мене можуть оцінити тільки слухачі. Але, на мою думку, я відповіла не погано, та і не досконало. На оцінку 10 з 12-ти, думаю, заслуговую. Але, я як учень все таки, можливо, правильно оцінити себе не можу, думаю, вам краще знати, на скільки балів я відповіла».

2. «На мою думку, доповідь вийшла досить вдалою. Я дотримався субординації, привітався з групою та був у належному вигляді, тобто, одягнений в офіційно-діловому стилі. Розповідь була досить стислою, що я б відніс до позитивного. Також я не можу вважати іï̈ чистою та зрозумілою мовою, адже деколи затинався та міняв слова місцями, за що вибачаюся перед студентами. Матеріал подав не досить цікаво, чим не викликав інтерес в студентів, що я вважаю негативним».

3. «Я вважаю, що мій виступ був досить цікавий, тому що, я доступно пояснила, що ж таке термін арго і суржик, добавила до розмови смішний факт про себе. Також додала критику в самооцінку, мій виступ був сприйнятий, але було мало емоцій і не все сказано так, як я запланувала! Тому дякую вам за ваше оцінення, а моєю оцінкою буде 9».

4. «В цілому мій виступ мені сподобався. Я намагалася доступно донести інформацію до своїх слухачів, використовувала усі джерела, що були під рукою. Розкрила майже усі питання, що були поставлені переді мною. Єдине, що би я хотіла добавити, це впевненості, і небоязні публіки».
5. «Я вважаю, що цілком впоралася із поставленою задачею. Оскільки розпочинаючи розповідь, я застосувала прийом «гра слів», що й викликало позитивні емоції та зацікавленість. Що стосується доповіді, можу підмітити лаконічність розповіді. В ній не було нічого зайвого та використовувались зрозумілі всім повсякденні слова та вирази, що і дало мені змогу бути зрозумілою та почутою. Як би це не виглядало самозакохано, але мінусів в розповіді не помітила».

6. «На мою думку, в моєму виступі щодо офіційно-ділового стилю я змогла передати його чітке значення та які мовні риси потребує офіційно-діловий стиль. Також я зазначила у своєму виступі, де саме може використовуватись офіційно-діловий стиль у сфері фармації. Також потрібно зазначити, що у моїй розповіді не було «родзинки», тобто я не змогла достатньо зацікавити слухачів своїм виступом. Дивлячись на це, я можу зробити висновок, що потрібно саморозвиватися та вдосконалюватися у різних мовних стилях. Моя оцінка - 8».

Зауважимо, що робота над текстом продовжується. Разом із студентами аналізують грамотність написання тексту, виокремлюють граматичні, стилістичні, психологічні аспекти.

Значну зацікавленість викликає самооцінка при проведенні діалогів (тему і перелік запитань студенти вибирають самостійно).

1. «Самооцінка - це класна і цікава річ. Оскільки моя відповідь $є$ випадковою і не знаючи питань, я не змогла підготуватись до відповіді, то воно було досить непогано. Але зважаючи на те, що я не змогла зразу відповісти на перше запитання, настрій для продовження даного діалогу був дещо негативний. Аналізуючи свою відповідь, я могла б ії трохи змінити. Проте, я вважаю, що моя відповідь має шанс отримати високу оцінку. Оцінюючи себе, я б поставила 9 балів».

2. «Змістовність+. Переживання -. Невпевненість -. Вміння «викручуватись» із ситуації +. Швидкі відповіді +. Оцінка - 10».

3. «На мою думку, я задавала питання влучні і зрозумілі, але можливо не правильно складені. Мені здається, я запитувала потрібні питання і ми з групою досить багато дізнались про Вікторію. Я вважаю, що я могла б поставити краще сформульовані питання, тому це $є$ моїм мінусом. Оцінка - 7».

4. «Надаю перевагу починати з плюсів стосовно самооцінки. Перш за все мені сподобалось спосіб викладу думок і чіткість висловлення, власне враховуючи невеликий обсяг часу. Також використання фразеологізмів, вчасність, готовність швидко під- 
тверджувати власні переконання, бо для себе відповідь вже були підсвідомо надані. На жаль мені не припало до душі те, що я не змогла відповісти на всі запитання. Можливо, одним з мінусів було те, що я не змогла зацікавити інтерв’юерку як мені б цього хотілось, адже історія вибору професії пройшла багато кіл оповідям друзям та знайомим і втратила для мене індивідуальну цінність. В міру можливостей рецензування власної самооцінки, я можу дозволити собі поставити одинадцять балів».

5. «Я вважаю, що я влучно і тактовно поставила запитання своїй співбесідниці, вклалась у часові рамки, та поступово розвивала насиченість розмови. Так, були деякі неточності, можливо граматичні помилки, русизми - одним випадком. Я розумію свої помилки та прагну їх виправити».

У науковій школі професора А. В. Вихруща особлива увага звертається на експертні висновки, в основі яких, окрім коректного звернення, передбачено, як правило, 5 запитань. Назвемо декілька прикладів, зберігаючи авторський стиль, таких запитань від студентів першого курсу:

1. «1. Які соціальні, політичні, економічні умови потрібно змінити для того, щоб полегшити повне забезпечення всіма правами людей з інвалідністю?

2. Яка політика впроваджується в Україні стосовно осіб з інвалідністю в реалізації їх права на освіту?

3. Як часто люди з особливими потребами зустрічаються з проблемою дискримінації? Як правильно чинити опір?

4. Дайте будь ласка 5 порад людям які не можуть прийняти статус «Людина з особливими потребами».

5. Що може зробити кожен для полегшення життя людини з особливими потребами?»

2. «1. Чи можете ви описати контингент з яким працюєте?

2. Опишіть основні завдання вашої професії.

3. Поділіться своїм розпорядком дня. Скільки часу ви приділяєте роботі, навчанню, сім'ї?

4. Виділіть основні риси характеру, якими володіють люди вашої професії.

5. Коли ви почали цікавитись і поглиблено вивчати свою професію? Як ви до цього дійшли?»

3. «1. Що Ви завжди відчуваєте, коли спілкуєтеся 3 людьми з особливими потребами?

2. Як підтримуєте їх, адже люди з особливими потребами потребують і слів?

3. Які методи діяльності застосовуєте для полегшення життя таких людей?
4. Були моменти, коли хотілося залишити свою діяльність?

5. Чи виникали у Вас думки про те, що Вашу роботу не розуміють звичайні люди?»

4. «1. Як варто спілкуватися з людьми з особливими фізичними потребами?

2. Що на Вашу думку найбільше впливає на психологічний стан цих людей?

3. Чи $\epsilon$ проблеми в особистому житті у ваших пацієнтів через їх стан здоров'я, адже це досить важливий аспект у лікуванні?

4. Як кожен з нас міг би допомогти?

5. Чи існують у пацієнтів комплекси через ці фізичні особливості?»

5. «1. Як підбадьорити людину з особливими фізичними потребами, щоб не зачепити ії гідності?

2. Як допомогти адаптуватися таким людям після хвороби?

3. Як навчити суспільство правильно реагувати на людей з особливими фізичними потребами?

4. Як діяти, якщо людину з особливими фізичними потребами хтось ображає?

5. Як допомогти реалізувати себе людям з особливими фізичними потребами?»

Як бачимо, окрім оцінки грамотності, можемо виокремити такі аспекти, як емпатія, психологічна культура, толерантність.

У 2021 р. майбутні стоматологи готували есе «Спілкування лікаря 3 дітьми-сиротами». Зауважимо, що міждисциплінарний підхід, в основі якого поєднання української мови за професійним спрямуванням, медицини, педагогіки, психології, змінює атмосферу практичних занять, підвищує зацікавленість, результативність роботи. Розглянемо декілька прикладів, традиційно не змінюючи авторський стиль.

1. «Оскільки у дітей-сиріт відсутні батьківська турбота, любов, то вони є більш вразливими. Лікар, який працює з такою дитиною має забезпечити іï насамперед підтримкою. Задля цього лікарю необхідно володіти певними психологічними навичками, щоб передбачити різні варіанти поведінки дитини-пацієнта, встановити з нею зв'язок. Якщо йому це вдасться, то дитина розкриється, розповість про свої проблеми. Педіатру варто бути терплячим і в міру наполегливим, адже не всі діти легко йдуть на контакт. Насамперед лікар мусить вислухати маленького пацієнта та вербальними і невербальними засобами проявити емпатію. Отже, встановлене безтурботне спілкування з дітьми-сиротами свідчить про професіоналізм лікаря». 
2. «1. Уважно вислухайте дитину, прагніть до того, щоб підліток зрозумів, що він вам не байдужий і ви готові зрозуміти і прийняти його. Не перебивайте і показуйте свого страху. 2. Відносьтесь до нього серйозно, з повагою. З. Запропонуйте свою підтримку і допомогу. 4. Впевнено спілкуйтесь 3 сиротою. Саме це допоможе їй повірити у власні сили. 5. Використовуйте слова, речення, які будуть сприяти встановленню контактів: розумію, звичайно, відчуваю, хочу допомогти. 6. В розмові 3 дитиною дайте зрозуміти їй, що вона необхідна і унікальна як особистість. 7. Вмійте слухати, довіряйте і викликати довіру. Отже, поради які я перерахувала можуть вам допомогти налаштувати позитивне та продуктивне спілкування 3 дітьми сиротами, щоб уникнути непорозумінь».

3. «Лікар повинен бути для дитини психологом, вміти вислухати, зрозуміти їі проблеми, в будь-який момент підтримати, тому що у дітей-сиріт немає батьківської ласки, опори, любові. 3 дітками потрібно говорити часто, тому що мовленнєвий розвиток дитини теж $є$ важливим аспектом загального психічного розвитку. Спілкування таких дітей носить поверховий, формальний характер і відрізняється емоційною бідністю. Тому лікар повинен вміти зацікавити дитину. Потрібний спеціальний підхід, який заснований на інтересах та поглядах на життя дитини. Під час спілкування лікар повинен виявляти високий рівень психологічного комфорту в безпеці, любові, спілкуванні».

У процесі подальшої роботи студенти редагують тексти, обговорюють стилістичні, граматичні, логічні аспекти. Це використовується і при написанні перших наукових текстів. Методика «раннього наукового старту» (А. В. Вихрущ) підтверджує свою ефективність.

Висновки та перспективи подальших досліджень. На основі вищесказаного можна виокремити декілька перспективних напрямків подальших досліджень. Очевидно, що кожна спеціальність має свої характерні прояви спілкування з пацієнтами. Саме тому при підготовці методичних матеріалів, написанні монографій та дисертацій доцільно поєднувати загальні тенденції, властиві для успішного спілкування, із закономірностями професійної діяльності (стоматологи, фармацевти, фізіотерапевти, сімейні лікарі, хірурги та ін.). Свої специфічні особливості має вік, стать, вид захворювання пацієнта, соціальні особливості. Необхідно звернути увагу на цю проблему, починаючи з першого курсу і при вивченні усіх предметів. Доцільно провести уточнення пріоритетів у системі підвищення кваліфікації викладачів, а також внести зміни в навчальні плани для аспірантів і докторантів.

\section{Список літератури}

1. Бобрівець М. День людей з інвалідністю [Електронний ресурс] / М. Бобрівець. - Режим доступу : https:// www.tenews.org.ua/post/show/1607067492-lyudi-zinvalidnistyu-nasampered-lyudi.

2. Вихрущ А. В. Діти з особливими потребами в умовах реформування системи місцевого самоврядування / А. В. Вихрущ, Т. В. Яблонь, І. Д. Драч // Медична освіта. - 2020. - № 4. - С. 10-15.

3. Вихрущ А. В. Освітня політика Польщі (діти здорові та з особливими потребами) / А. В. Вихрущ // Молодь і ринок. - 2020. - № 2 (181). - С. 18-23.

4. Всемирный доклад об инвалидности / ВО3, Всемирный банк. - 2011. - 28 с.

5. Засенко В. Діти з особливими потребами: пріоритетні напрямки державної політики України в галузі освіти, соціального захисту й охорони здоров'я / В. Засенко, А. Колупаєва // Особлива дитина: навчання і виховання. - 2014. - № 3. - С. 20-29.

6. Конвенція про права осіб з інвалідністю від 13.12.2006 [Електронний ресурс]. - Режим доступу : https://zakon.rada.gov.ua/laws/show/995_g71\#Text.

7. Путівник для батьків дітей з особливими освітніми потребами : навч.-метод. посіб. : у 9 книгах / за заг. ред. А. Колупаєвої. - К., 2010. - 363 с.

8. Садова I. І. Інклюзія у закладах загальної середньої освіти України: тенденції розвитку : монографія / I. I. Садова. - Дрогобич : Посвіт, 2020. - 448 с.

9. Чупахіна С. Сучасні підходи у підготовці майбутніх педагогів до інклюзивного навчання дітей з особливими потребами / С. Чупахіна // Освітній простір України. 2017. - № 11. - C. 114-122.

10. Andrew Symons B. A curriculum to teach medical students to care for people with disabilities: development and initial implementation / Andrew B. Symons, Denise McGuigan, A. Elie // BMC Medical Education. - 2009. No. 9. - URL : https://bmcmededuc.biomedcentral.com/ articles/10.1186/1472-6920-9-78.

11. Development of students-foreigners" communicative competence by means of information technologies under the conditions of the medical university / A. Vykhrushch, N. Fedchyshyn, T. Khvalyboha [et al.] // International Journal of Higher Education. - 2020. - Vol. 9, No. 6. P. 276-285. 
12. Marat E. Rodzina z dzieckem niepełnosprawnym / E. Marat // W ks. : Psychologia rodziny / I. Janicka, H. Liberska. - Warszawa : Wydawnictwo Naukowe PWN SA, 2014. - 682 s.

\section{References}

1. Bobrivets, M. Den liudei z invalidnistiu [Day of people with disabilities]. Retrieved from: https://www.tenews.org. ua/post/show/1607067492-lyudi-z-invalidnistyu-nasampered-lyudi [in Ukrainian].

2. Vykhrushch, A.V., Yablon, T.V., \& Drach, I.D. ( 2020).

Dity z osoblyvymy potrebamy $\mathrm{v}$ umovakh reformuvannia systemy mistsevoho samovriaduvannia [Children with special needs in the context of reforming the system of local self-government]. Medychna osvita - Medical Education, 4, 10-15 [in Ukrainian].

3. Vykhrushch, A.V. (2020). Osvitnia polityka Polshchi (dity zdorovi ta z osoblyvymy potrebamy) [Education policy of Poland (healthy children and with special needs)]. Molod $i$ rynok - Youth and the Market, 2 (181), 18-23 [in Ukrainian].

4. (2011). Vsemirnyiy doklad ob invalidnosti [World Disability Report]. VOZ: Vsemirnyiy bank - WHO: World Bank [in Russian].

5. Zasenko, V., \& Kolupaieva, A. (2014). Dity z osoblyvymy potrebamy: prioritetni napriamky derzhavnoi polityky Ukrainy v haluzi osvity, sotsialnoho zakhystu v okhoroni zdorovia [Children with special needs: priority directions of the state policy of Ukraine in the field of education, social protection and health care]. Osoblyva dytyna: navchannia i vykhovannia - Special Child: Education and Upbringing, 3, 20-29 [in Ukrainian].

6. (2006). Konventsiia pro prava osib z invalidnistiu [Convention on the rights of persons with disabilities]. zakon.rada.gov.ua. Retrieved from: https://zakon.rada.gov. ua/laws/show/995_g71 [in Ukrainian].

7. Kolupaieva, A. (2010). Putivnyk dlia batkiv ditei z osoblyvymy osvitnimy potrebamy [Guide for parents of
13. Vychrushch A. Samotność studentów pierwszego roku na uniwersytetach medycznych / A. Vychrushch // Pedagogika katolicka. - 2020. - No. 26 (1). - P. 73-79.

children with special educational needs]. Educationalmethodical manual. Kyiv [in Ukrainian].

8. Sadova, I.I. (2020). Inkliuziia u zakladakh zahalnoi serednioi osvity Ukrainy tendentsii rozvytku [Inclusion in general secondary education institutions of Ukraine: development trends]. Drohobych: Posvit [in Ukrainian].

9. Chupakhina, S. (2017). Suchasni pidkhody u pidhotovtsi maibutnikh pedahohiv do inkliuzyvnoho navchannia ditei z osoblyvymy potrebamy [Modern approaches in the preparation of future teachers for inclusive education of children with special needs]. Osvitnii prostir Ukrainy Educational Space of Ukraine, 11, 114-122 [in Ukrainian].

10. Andrew B. Symons, Denise Mc Guigan, \& Elie, A. (2009). A curriculum to teach medical students to care for people with disabilities: development and initial implementation BMC Medical Education, 9, 78. Retrieved from: https://bmcmededuc.biomedcentral.com/articl es/10.1186/1472-6920-9-78.

11. Vykhrushch, A., Fedchyshyn, N., Khvalyboha, T., \& Drach, I. (2020). Development of students-foreigners" communicative competence by means of information technologies under the conditions of the medical university. Mizhnarodnyi zhurnal vyshchoi osvity - International Journal of Higher Education, 9, 6, 276-285.

12. Marat, E. (2014). Rodzina z dzieckem niepełnosprawnym. W ks. Janicka, I., Liberska, H. Psychologia rodziny Warshawa, Polshcha: Wydawnictwo Naukowe PWN SA.

13. Vychrushch, A. (2020). Samotność studentów pierwszego roku na uniwersytetach medycznych. Pedagogika Katolicka, 26 (1), 73-79. 